Premiere Educandum: Jurnal Pendidikan Dasar dan Pembelajaran

Volume 11 (1) 15 - 29 June 2021

ISSN: 2088-5350 (Print) / ISSN: 2528-5173 (Online)

Doi: $10.25273 /$ pe.v11i1.7817

The article is published with Open Access at: http://e-journal.unipma.ac.id/index.php/PE

\title{
Development of mind mapping-based comics to improve math learning outcomes
}

Trimurtini $\bowtie$, Universitas Negeri Semarang

Mira Amalia Setyani, Universitas Negeri Semarang

Elok Fariha Sari, Universitas Negeri Semarang

Nursiwi Nugraheni, Universitas Negeri Semarang

$\bowtie$ trimurtinipgsd@mail.unnes.ac.id

\begin{abstract}
This study aims to develop, study the feasibility and effectiveness of mathematics comic media based on mind mapping for fifth-grade students of public elementary schools in Demak. The method used is the Sugiyono Research and Development model consisting of 7 steps. The data analysis technique used descriptive statistics, t-test, z-test and n-gain. The results showed the development process of mathematical comic media based on mind mapping on speed and discharge topics with the local cultural background of Demak city. Media was assessed by material, media, and language experts, and It showed valid results and very feasible to be implemented. This media's effectiveness is indicated by the improvement of the Students' learning outcomes and learning achievement. Students and teachers' response about this media shows positive responses because the comic media are practical and complete content, such as (material, question, assignment, solution, and evaluation). The conclusion is learning media has been successfully developed. Mathematics comic media based on mind mapping is very feasible and practical used in learning mathematics, and it is efeffectively improvements' learning.
\end{abstract}

Keywords: Comic, Elementary School, Mathematics, Mind Mapping.

Received 15 November 2021; Accepted 02 February 2021; Published 01 June 2021

Citation: Trimurtini, T., Setyani, M.A., Sari, E.F., \& Nugraheni, N. (2021). Development of mind mapping-based comics to improve math learning outcomes. Premiere Educandum : Jurnal Pendidikan Dasar dan Pembelajaran, 11(1), 15 - 29. Doi.org/10.25273/pe.v11i1.7817

\section{(cc) BY-NC-SA}

Copyright (C2021 Premiere Educandum : Jurnal Pendidikan Dasar dan Pembelajaran

Published by Universitas PGRI Madiun. This work is licensed under the Creative Commons Attribution-NonCommercial-

ShareAlike 4.0 International License. 


\section{INTRODUCTION}

Mathematics is one of the areas of science that can develop thinking and arguing (Sumartini, 2016), contribute to solving daily problems, and provide or support improving science and technology (Hardman, 2019). The implementation of elementary school mathematics learning in the 2013 curriculum aims to introduce the scope of number materials, geometry and measurement, and data management (Nasarudin, 2013). The direction of mathematics learning in elementary school encourages students to find out from various sources, to solve problems to formulate simple problems in their daily lives. Further, in solving problems, students can collaborate by emphasizing logical and creative thinking, not just mechanistic thinking (Ministry of Education and Culture, 2016).

However, based on the observation in some schools shows that Mathematics learning in Indonesia does not implement optimal, and it needs improvement. This statement is supported by trends in Mathematics and Science Study (TIMSS) research in 2015 , which shows that Indonesia is ranked 45th out of 50 participating countries with a score of 397 out of a high score of 625 (Mullis, Martin, Foy, \& Hooper, 2015). Also, to the TIMMS results, the low mathematical ability in Indonesia is shown in government studies conducted by the Ministry of Education through the Indonesia National Assessment Program (INAP) (Ministry of Education and Culture, 2020) that in 2016, approximately $77.13 \%$ of elementary school students throughout Indonesia had low competencies. The causes of students' low math learning results derived from the students themselves and the teacher or the learning process, whether students have difficulty understanding or accepting the material because the teacher uses inappropriate teaching techniques. (Siregar \& Rosaliana, 2017).

Math learning problems also occurred in grade V of SD N Gugus Sultan Agung. Math Learning problems also happened in the 5th grade of SDN Gugus Sultan Agung, whether the teacher did not utilize learning media to involve students' activity. At the time of mathematics learning, most students were still less interested in participating in learning activities. Furthermore, the learning resources used have not varied. The learning activities are quite varied on certain occasions 2 out of 5 teachers of SD N Gugus Sultan Agung have applied the discovery learning model, one other teacher has applied a problem-solving model during math learning activities. The problem is supported by data of Final Assessment of Semester 1 (PAS 1) of SD N Gugus Sultan Agung students, out of 134 students, there are $83(62 \%)$ students who were still under the Minimum Completedness Criteria (KKM) (70). Preliminary analysis results showed students had the most challenging time in completing material about distance, time, speed and discharge.

Thus, it is necessary to update the learning media, the need for completeness and conformity of learning materials with the curriculum, and the display of learning media. Students and teachers need more exciting and effective media to learn math material in class V, primarily about speed and discharge. Using learning media allows students to learn independently and encourage them to be active in learning (Suryatin \& Sugiman, 2019). Some learning media have been offered, but teachers and students prefer to use comic media. Therefore, it is necessary to update the learning media, complete and adjust the learning materials with the curriculum, and display it.

Students are interested in using comics in learning because it is comfortable reading material. Also, comics can help students understanding learning materials (Suryatin \& Sugiman, 2019). A comic is a series of images inserted into a box containing the entire story series (Buchori \& Setyawati, 2015). The comics can help teachers to convey abstract concepts into more concrete and exciting forms. The comics also help students find a new information and improve student learning activeness (Nugraheni, 2017). Comic learning media has been widely researched, such as research on comics in digital form is also useful in improving students' creative thinking (Putra \& Iqbal, 2004). Another study showed that 
comics effectively read Indonesian understanding in grade $\mathrm{V}$ elementary school (Dewi, Ganing, \& Wayan, 2020). The development of comics is also used for various mathematical learning materials, including flat-build geometry (Kurniati, Rahimah, \& Rusdi, 2017), fractions (Nova \& Yunianta, 2018) to solve mathematical problems (Gumilang \& Indarini, 2019). Contextual-based mathematics comics on rectangular material can improve the learning outcomes of grade VII students (Nendasariruna, MAsjudin, \& Abidin, 2018).

Besides comics are attractive and useful in Mathematic learning, it also helps students be more active and brainstorm students' thinking processes, especially for speed and discharge materials. In this material, students are required to use existing formulas, but students are also encouraged to solve the speed and discharge problems by using reasoning and thinking processes. Mind mapping is one way to optimize the thinking processes with working systems to reach out in all directions and capture the mind from any angle (Buzan, 2012). Mind mapping enables brains to work based on their respective portions and helps students use the brain's potential (Pajarini, Putra, \& Manuaba, 2014). Besides, mind mapping as an organizational thinking tool makes it easier to put information into the brain and take information outside of the brain (Zahro, Degeng, \& Mudiono, 2018). Besides, By using mind mapping, students actively participate in the teaching-learning process and motivate to follow the learning (Arsana, Suarjana, \& Arini, 2019). Moreover, a study combining the mind map with the STAD model showed better student learning outcomes (Zahro et al., 2018). Other research shows that a mind map can effectively achieve optimal creative thinking, but the research was carried out at the high school level (Zubaidah, Fuad, Mahanal, \& Suarsini, 2017).

Researchers see the importance of contextual aspects in learning will bring comic media(Pajarini et al., 2014) more meaningful. Thus, this research developed a comic learning media based on mind mapping on speed and discharge materials for grade $\mathrm{V}$ elementary students and equipped with contextual aspects in background stories that elevate local culture in Demak Regency. Based on this background, the purpose of this research is to develop, review the feasibility and effectiveness of mind mapping-based mathematics comic learning media to improve student learning outcomes of class $\mathrm{V}$ materials of SD N Gugus Sultan Agung Demak Regency.

\section{METHODS}

This research uses the research and development (R\&D) method. The product developed is a mind mapping based mathematics comic on speed and discharge material in class $\mathrm{V}$ SDN Gugus Sultan Agung.

\section{Research Subjects}

The research subjects in the product trial activities were 20 students of grade V SD N Sari 1 with the composition of 11 boys and nine girls and the usage test was 30 students of grade V SD N Banjarsari 1 with a composition of 14 boys and 16 girls. The age of the study subjects ranged from 11 to 12 years. Sampling was done by cluster random sampling technique.

\section{Design and Procedure}

The development model used is a development model adapted from sugiyono development model adapted from Brog and Gall, consisting of 10 steps. This research uses only 7 steps from 10 steps as in Figure 1. Image caption 1: (1) discover potential and problems; (2) data collection through observation, interviews, questionnaires and literature studies; (3) designing teaching media design; (4) media validation by design experts; (5) design revision based on the advice of expert lecturers of materials, media, 
and language; (6) trial of small-scale products; (7) revision of teaching media products; (8) trial use of teaching media; (9) product revision; (10) mass.

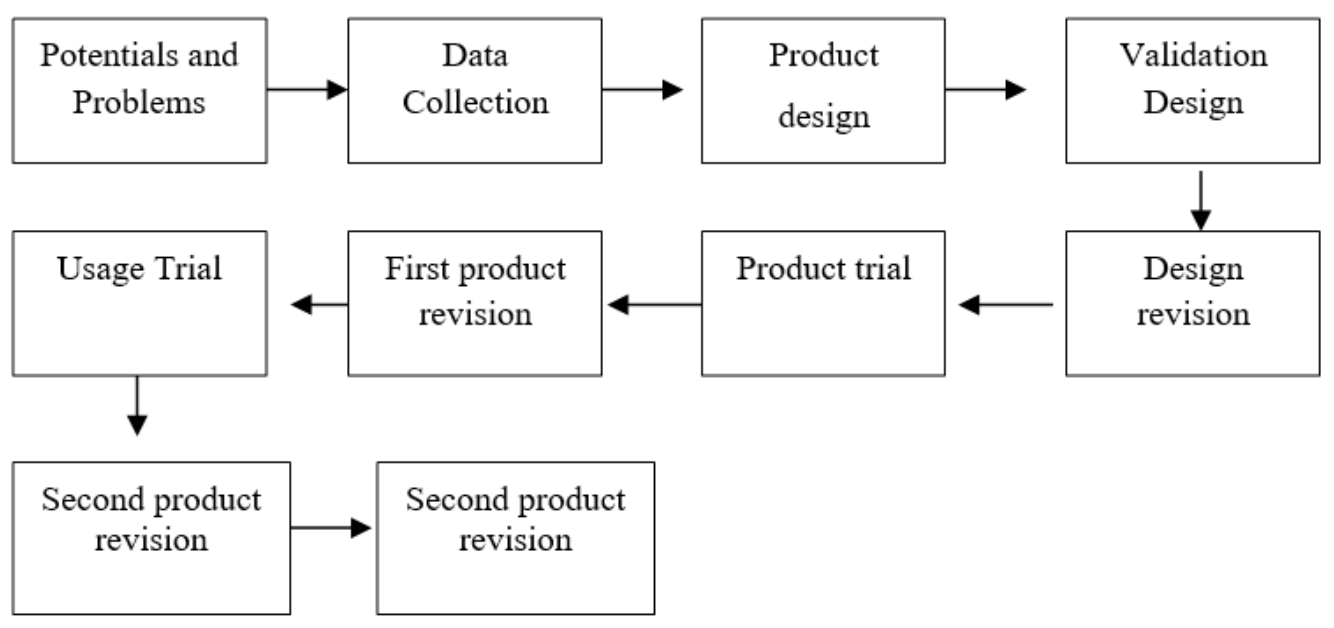

FIGURE 1. Research and development steps according to Sugiyono (Sugiyono, 2015)

\section{Materials/Instruments and Indicators}

Data collection techniques were carried out through test and non-test techniques (needs questionnaires, interviews, rubrics and response questionnaires). The test instrument has been tested for validity and eligibility with a reliability value of 0.770 , meaning a reliable test instrument. Experts have validated Non-test instruments.

\section{Data Analysis}

Data analysis techniques begin with a required test to release quantitative data of students' learning outcomes, namely normality and homogeneity tests. Next, it is followed by an appealing test of pretest and posttest learning results of speed and discharge materials, to test the difference in average learning outcomes and completeness individually, $\mathrm{z}$ test to test classical completeness and n-gain test to test improved student learning outcomes.

\section{RESULTS}

\section{Product Design}

After curriculum analysis activities, indicator development, lesson plan development, and teaching materials development before conducting design activities in learning media product design activities. Learning media is part of the learning device. After curriculum analysis activities and learning device development were carried out, researchers began designing comic media products based on mind mapping and central Java's cultural background, demak city.

The inside of this comic design includes the design of the front cover (Figure 2a), the characters in the comic (Figure $\mathbf{2 b}$ ), the contents of the material, sample questions, summaries in the form of mind maps, and practice questions. Then the contents are divided into two materials, namely, speed material and discharge material. Each section described understanding, its application in daily life with the cultural background of demak city. The place's background is in the elementary school's cluster area, where the research is located Demak. It can be seen in the comics there is The Great Mosque of Demak and The Great Grebek Night Market of Demak. The choice of venues in Demak 
Grand Mosque and Grebek Besar Demak Night Market, because the cluster is in Demak, and the students can find both places in their daily lives, and it is an effort to introduce both places as the pride of Demak City to readers.
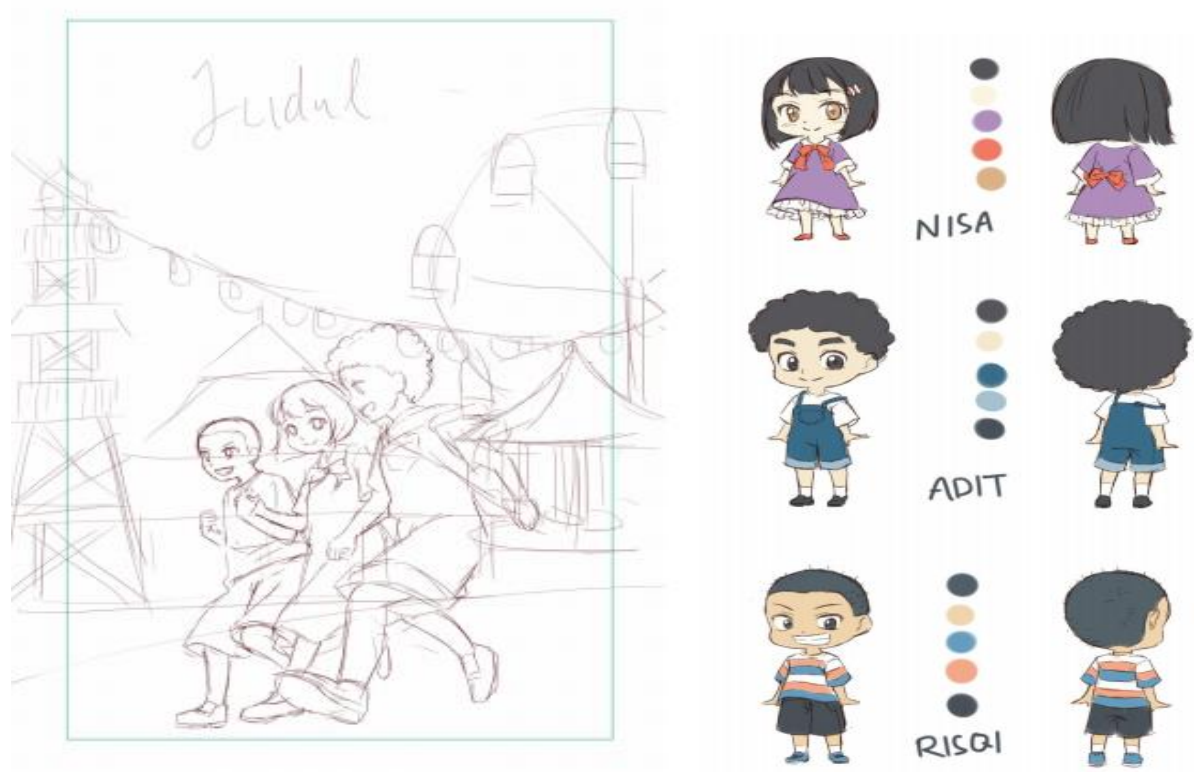

FIGURE 2. (a) Comic cover page design, (b) Comic book character design

At the end of each part of the material is equipped with a mind map (Figure 3), which serves as a summary and linkage between several submateries.

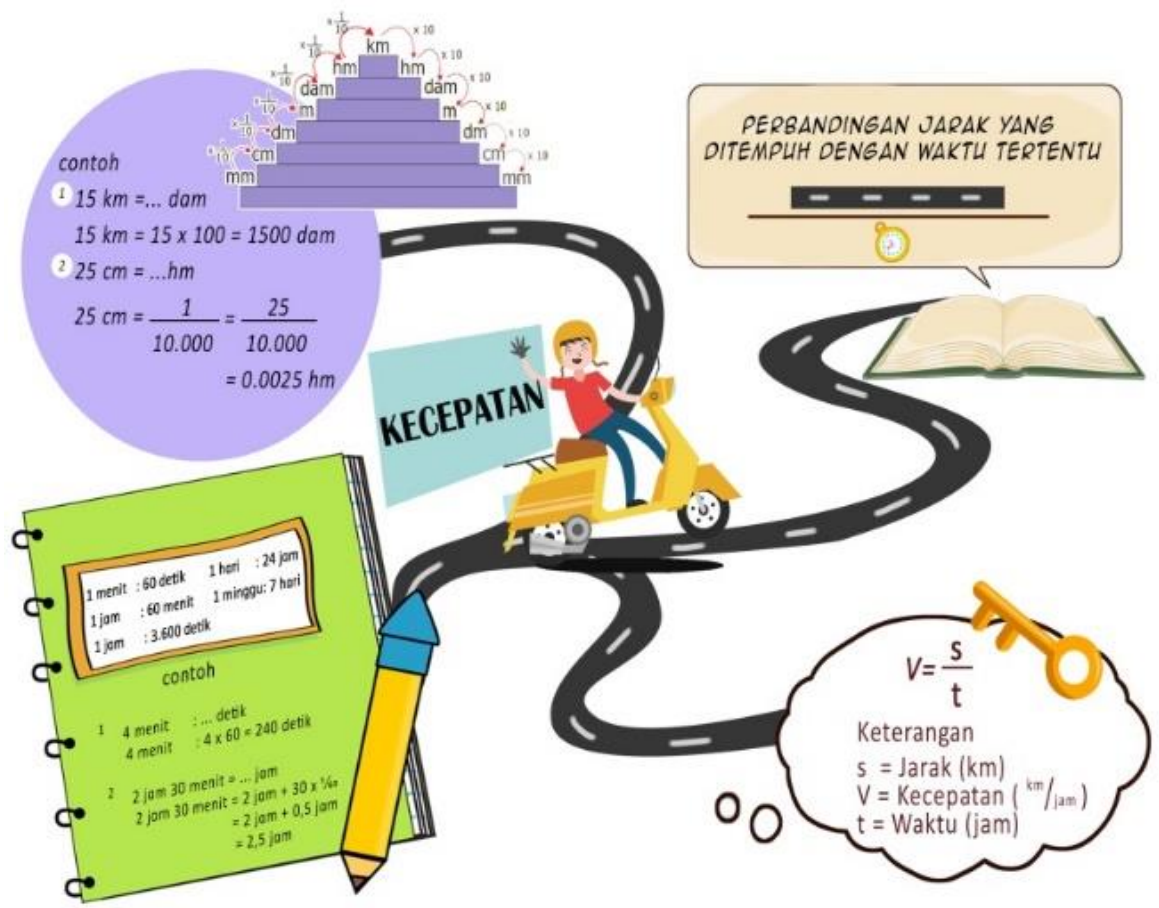

FIGURE 3. Mind mapping on comics for speed materials

Aside from the content aspect, the media aspect of learning mathematics comics based on mind mapping agreed by teachers and students with the characteristics of comic 
media as follows: it has a size of $15 \mathrm{~cm} 22 \mathrm{~cm}$, the type of font is anime ace, there are 3-5 number of characters in the comic, and the comic is printed on ivory paper with a thickness of 230 grams / m2.

\section{Design Validation}

Product validation aims to determine the feasibility of mind mapping-based mathematical comic media before it is used for trial and test activities. Lecturers carry out media validation with areas of learning skills and learning media. Material validation is done by mathematics lecturers, while Indonesian lecturers do language validation. Examples of students' worksheet speed and discharge material can be seen in figures 1 and 2 . The results of the assessment of the three experts are presented in Table 1.

TABLE 1. Mind mapping based mathematics comic media feasibility assessment

\begin{tabular}{cccccc}
\hline No & Expert & $\begin{array}{c}\text { Maximum } \\
\text { Score }\end{array}$ & Score Obtained & Percentage & Criteria \\
\hline 1. & Media & 70 & 60 & $86 \%$ & Very Feasible \\
2. & Materi & 45 & 39 & $87 \%$ & Very Feasible \\
3. & Language & 40 & 35 & $88 \%$ & Very Feasible \\
\hline
\end{tabular}

Based on Table 1 assessment of media experts, material and language of mind mapping-based mathematics comics meet very valid criteria and worthy of being used as a learning medium in product trials and usage tests in grade 5 elementary school. Before using this media, there are several parts of comics need to be revised according to expert advice.

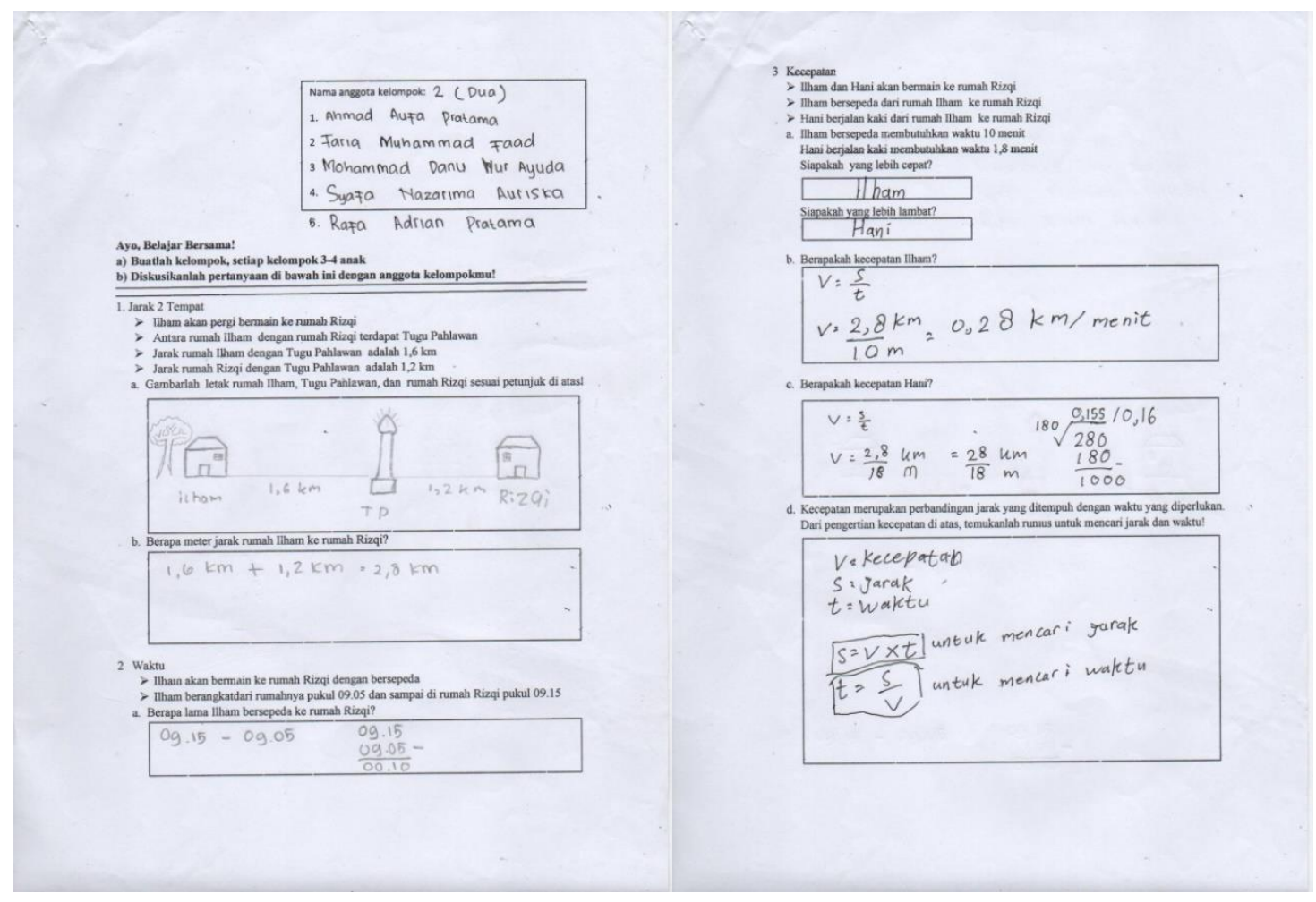

FIGURE 5 Worksheets of Student Speed Materials 


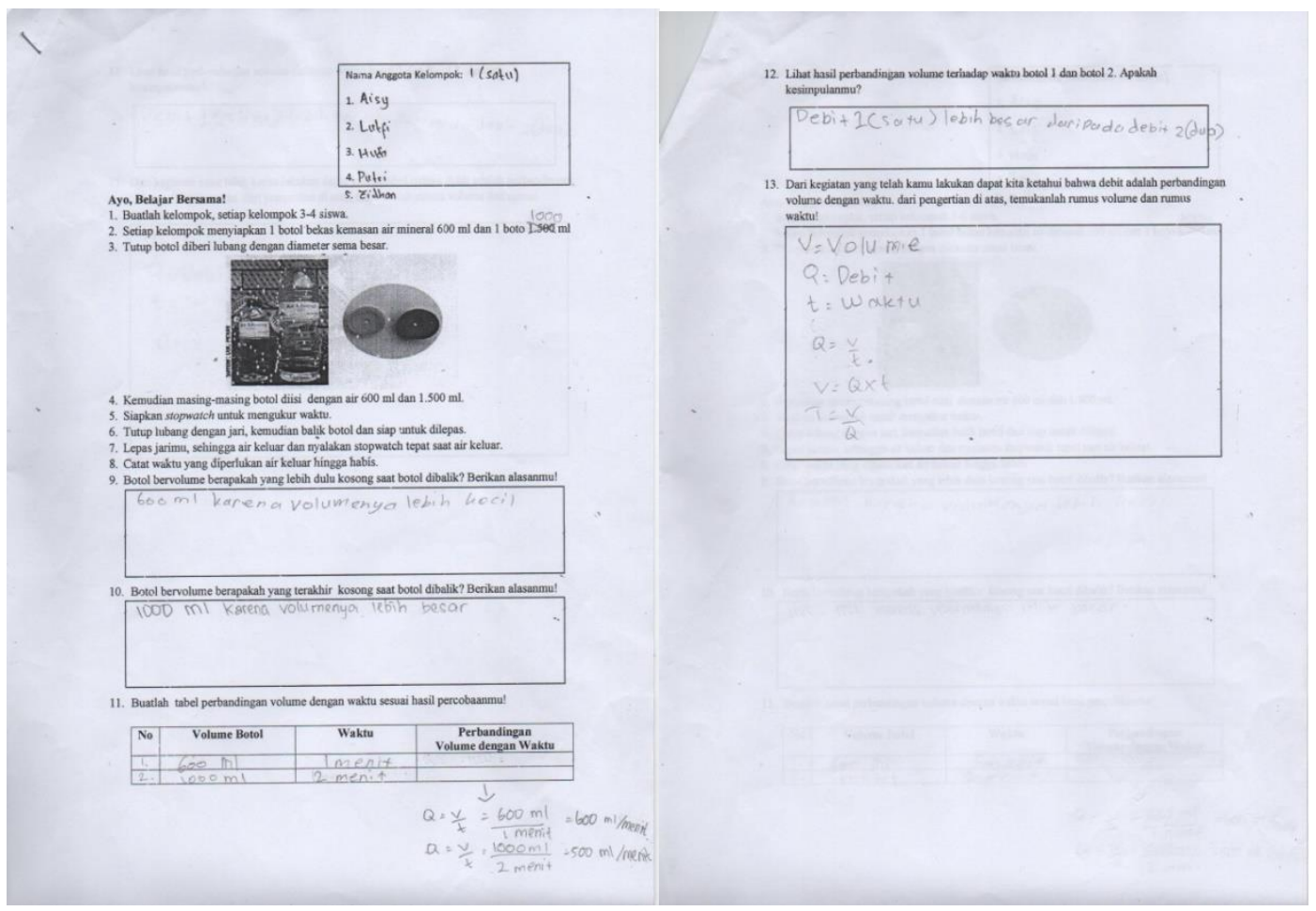

FIGURE 6. Student worksheets of debit materials

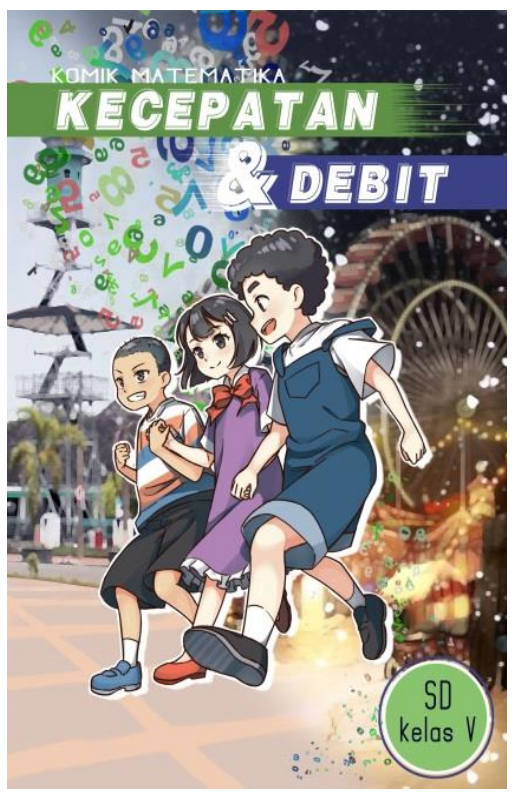

(a)

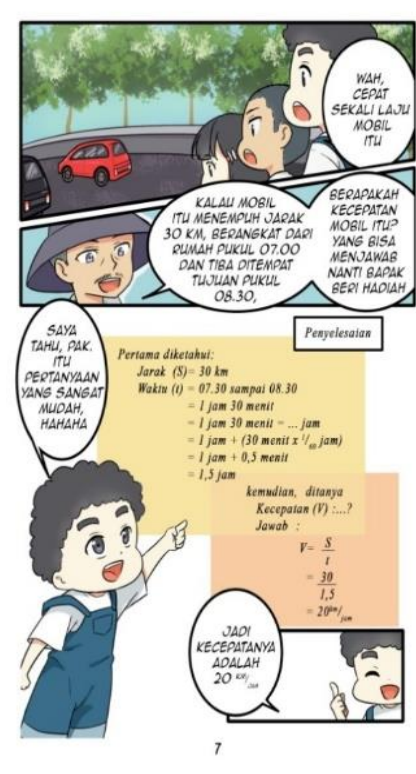

(b)

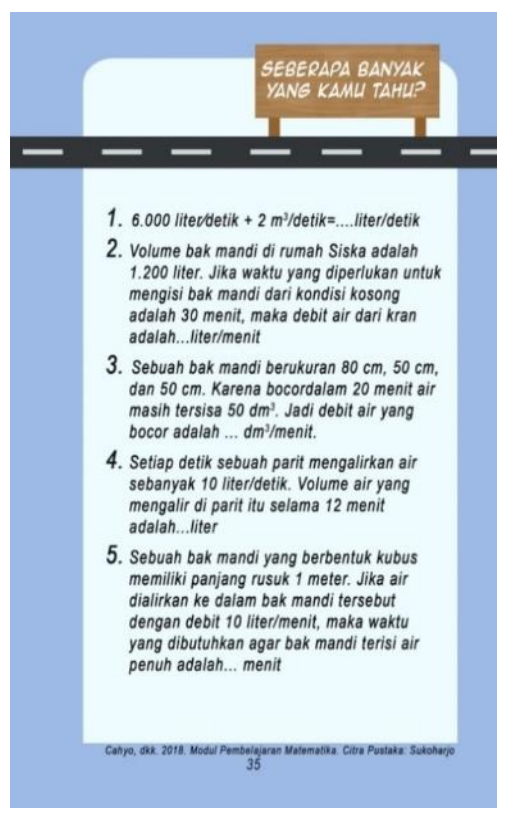

(d)

FIGURE 4. (a) Cover page, (b) Content page, (c) Problem practice page

\section{Design Revision}

Design revisions are based on suggestions and comments from experts who have done product validation. Some of the revised sections are as follows: (1) expert media advice: class writing on the cover page is created in the bottom right circle, add a background in the mind map to make it more interesting, explain the page number; (2) expert material 
advice: correct the sentence definition of discharge material, correct errors in how to calculate in the example of speed problem, fix problem exercises to be more contextual and logical; (3) linguist advice: use conversational language with effective and flexible sentences. Several pages on the revised comic are presented in Figure 4.

\section{Product trials \& usage tests}

Small-scale product trials were conducted in class V SD N Sari 1, while large-scale usage tests were conducted at SD N Banjarsari 1. At the end of the lesson, teachers and students were asked to fill out a response questionnaire to develop product improvement. The results of the calculation of learning results in the product trial and usage test are presented Table 2 and Table 3.

TABLE 2. Data value pretest and posttest SD N Sari 1

\begin{tabular}{cccccc}
\hline Action & $\begin{array}{c}\text { Highest } \\
\text { Rated }\end{array}$ & $\begin{array}{c}\text { Lowest } \\
\text { Value }\end{array}$ & Average & $\begin{array}{c}\text { Total Students } \\
\text { Completed }\end{array}$ & $\begin{array}{c}\text { Student Percentage } \\
\text { Complete }\end{array}$ \\
\hline Pretest & 77 & 53 & 65,1 & 3 & $15 \%$ \\
Posttest & 95 & 74 & 85,1 & 20 & $100 \%$ \\
\hline
\end{tabular}

TABLE 3. Pretest and posttest value data of SD N Banjarsari 1

\begin{tabular}{cccccc}
\hline Action & $\begin{array}{c}\text { Highest } \\
\text { Rated }\end{array}$ & $\begin{array}{c}\text { Lowest } \\
\text { Value }\end{array}$ & Average & $\begin{array}{c}\text { Total Students } \\
\text { Completed }\end{array}$ & $\begin{array}{c}\text { Student } \\
\text { Percentage } \\
\text { Complete }\end{array}$ \\
\hline Pretest & 77 & 47 & 63,7 & 12 & $40 \%$ \\
Posttest & 100 & 74 & 83,6 & 30 & $100 \%$ \\
\hline
\end{tabular}

Based on Table 2 and Table 3, the results of pretest and posttest learning of grade $\mathrm{V}$ students at SD N Sari 1 and grade V at SD N Banjarsari 1 have differences. In class V SD N Sari 1, the difference in pretest average value with posttest was 20 , while in class V SD N Banjarsari 11, the difference in pretest average value with posttest was 19.9. From the explanation, it was concluded that there was an increase in the average value of cognitive learning results before and after implementing of mathematics learning using mind mapping-based comic media in grade V SD N Sari 1 and SD N Banjarsari 1. Furthermore, he value data is carried out normality test. The normality test results of pretest and posttest grades of students of SD N Sari 1 and SD N Banjarsari 1 were presented

TABLE 4. Normality test results of pretest and posttest values of SD N Sari 1

\begin{tabular}{cccccc}
\hline Action & $\begin{array}{c}\text { Number of } \\
\text { Students }\end{array}$ & Average & Lo & $\begin{array}{c}\text { L Table } \\
\text { Sig 5\% }\end{array}$ & Conclusion \\
\hline Pretest & 20 & 65,1 & 0,182 & 0,19 & Data Berdistribusi Normal \\
Posttest & 20 & 85,1 & 0,145 & 0,19 & Data Berdistribusi Normal \\
\hline
\end{tabular}

TABLE 5. Normality test results of pretest and posttest values of SD N Banjarsari 1

\begin{tabular}{cccccc}
\hline Action & $\begin{array}{c}\text { Number of } \\
\text { Students }\end{array}$ & Average & Lo & $\begin{array}{c}\text { L Table } \\
\text { Sig 5\% }\end{array}$ & Conclusion \\
\hline Pretest & 30 & 63,7 & 0,114 & 0,161 & Data Berdistribusi Normal \\
Posttest & 30 & 83,6 & 0,073 & 0,161 & Data Berdistribusi Normal \\
\hline
\end{tabular}

Based on Table 4 and Table 5 Lo Pretest and Lo Posttest < L tables, thus Ho is rejected. This means that the data of learning results before (pretest) and after (posttest) 
math learning activities using comic media based on mind mapping in grade V SD N Sari 1dan SD N Banjarasari 1 distributed normally. Furthermore, homogeneity test results, the results of homogeneity test of pretest and posttest values of students of SD N Sari 1 and SD N Banjarsari 1 are presented in Table 6 and Table 7.

TABLE 6. Homogeneity test results of pretest and postest grades of SD N Sari 1 Students

\begin{tabular}{cccccc}
\hline Action & $\begin{array}{c}\text { Number of } \\
\text { Students }\end{array}$ & Average & Variance & F count & F table \\
\hline Pretest & 20 & 65,1 & 44,726 & \multirow{2}{*}{1,273} & 2,168 \\
Posttest & 20 & 85,1 & 35,147 & & \\
\hline
\end{tabular}

TABLE 7. Homogeneity test results of pretest and postest grades of students of SD N Banjarsari 1

\begin{tabular}{cccccc}
\hline Action & $\begin{array}{c}\text { Number of } \\
\text { Students }\end{array}$ & Average & Variance & F count & F table \\
\hline Pretest & 30 & 63,7 & 94,271 & \multirow{2}{*}{592} & 1,861 \\
Posttest & 30 & 83,6 & 59,206 & & \\
\hline
\end{tabular}

Based on Table 6 and Table 7 at SD N Sari 1 and SD N Banjarsari 1 obtained F calculate $<\mathrm{F}$ table, then $\mathrm{Ha}$ is accepted. This means that the data of learning results before and after mathematics learning activities using mind mapping-based comic media in grade V SD N Sari 1 and SD N Banjarasari 1 comes from the same variance. The paired sample ttest results of pretest and post-test scores of students of SD N Sari 1 and SD N Banjarsari 1 are presented in Table 8.

TABLE 8. Test results $t$ pretest value posttest SD N Sari 1

\begin{tabular}{ccccc}
\hline Action & Variance & $\begin{array}{c}\text { Correlation between 2 } \\
\text { Samples }\end{array}$ & t count & t table \\
\hline Pretest & 44,726 & 0,264 & $-11,650$ & 1,730 \\
Posttest & 35,147 & & & \\
\hline
\end{tabular}

TABLE 9. $t$ test results of pretest and postest grades of students of SD N Banjarsari 1

\begin{tabular}{ccccc}
\hline Action & Variance & $\begin{array}{c}\text { Correlation between 2 } \\
\text { Samples }\end{array}$ & t count & t table \\
\hline Pretest & 94,271 & 0,686 & $-15,274$ & 1,700 \\
Posttest & 59,205 & & & \\
\hline
\end{tabular}

TABLE 10. $N$ test results gain pretest and posttest scores of elementary school students $N$ Sari 1

\begin{tabular}{cccccc}
\hline Action & $\begin{array}{c}\text { Number of } \\
\text { Students }\end{array}$ & Average & $\begin{array}{c}\text { Difference in Value } \\
\text { Average }\end{array}$ & $\begin{array}{c}\text { Value } \\
\text { n-gain }\end{array}$ & Criteria \\
\hline Pretest & 20 & 65,1 & 20 & 0,57 & Sedang \\
Posttest & 20 & 85,1 & & & \\
\hline
\end{tabular}

Based on Table 8 and Table 9, test t grades of students of SD N Sari 1 and SD N Banjarsari $1 \mathrm{t}$ calculate $<\mathrm{t}$ table then Ha is accepted. This means that there are differences in learning outcomes between students who use mind mapping-based comic media and those who do not use mind mapping-based comic media in math learning grade V SD N Sari 1 and SD N Banjarasari 1. 
Furthermore, $\mathrm{n}$ gain test results at SD N Sari 1, and SD N Banjarsari 1 are presented in Table 10 and Table 11.

TABLE 11. $N$ test results gain pretest and postest value of SD N Banjarsari Students 1

\begin{tabular}{cccccc}
\hline Action & $\begin{array}{c}\text { Number of } \\
\text { Students }\end{array}$ & Average & $\begin{array}{c}\text { Difference in Value } \\
\text { Average }\end{array}$ & $\begin{array}{c}\text { Value } \\
\text { n-gain }\end{array}$ & Criteria \\
\hline Pretest & 30 & 63,7 & 19,9 & 0,54 & Sedang \\
Posttest & 30 & 83,6 & & & \\
\hline
\end{tabular}

Based on Table 11, the value of learning results before implementing mathematics learning using mind mapping-based comic media increased on average with $\mathrm{n}$ gain in grade V SD N Sari 1s of 0.57 and SD N Banjarsari 1 by 0.54 , both of which were included in the moderate criteria. The completeness of students' learning individually and the Criteria for Completeness is 70, tested with a one-party t-test. While the completeness of classical learning is at least $75 \%$ tested with the $\mathrm{z}$ test. The test results are described in Table $\mathbf{1 2}$.

TABLE 12. Results of learning completed test for students of SD N Banjarsari 1

\begin{tabular}{ccccc}
\hline Action & $\begin{array}{c}\text { Number } \\
\text { of } \\
\text { Students }\end{array}$ & $\begin{array}{c}\text { Results } \\
\text { calculation }\end{array}$ & Table values & $\begin{array}{c}\text { Learning Completedness } \\
\text { Criteria }\end{array}$ \\
\hline Posttest & 30 & t count 11,391 & t tabel 1,729 & $\begin{array}{c}\text { Individual completedness of } \\
\text { more than } 70 \\
\text { Classical learning }\end{array}$ \\
& & z count 2.58 & z tabel $-1,64$ & \begin{tabular}{c} 
completedness reaches $75 \%$ \\
\hline
\end{tabular}
\end{tabular}

TABLE 13 Recapitulation of Teacher and Student Responses

\begin{tabular}{|c|c|c|c|c|c|c|}
\hline \multirow[t]{2}{*}{ No } & \multirow[t]{2}{*}{ Aspects } & \multicolumn{2}{|c|}{$\begin{array}{l}\text { Response from } \\
\text { SDN Sari } 1\end{array}$} & \multicolumn{2}{|c|}{$\begin{array}{l}\text { Response from } \\
\text { SDN Banjarsari } 1\end{array}$} & \multirow[t]{2}{*}{ Criteria } \\
\hline & & Students & Teacher & Students & Teacher & \\
\hline 1 & $\begin{array}{l}\text { The media attracts and } \\
\text { motivates students in learning }\end{array}$ & $99 \%$ & $100 \%$ & $97 \%$ & $100 \%$ & $\begin{array}{c}\text { Very } \\
\text { Positive }\end{array}$ \\
\hline 2 & $\begin{array}{l}\text { Mind mapping helps } \\
\text { understand learning material }\end{array}$ & $98 \%$ & $100 \%$ & $99 \%$ & $100 \%$ & $\begin{array}{c}\text { Very } \\
\text { Positive }\end{array}$ \\
\hline 3 & The media create fun learning & $99 \%$ & $80 \%$ & $97 \%$ & $100 \%$ & $\begin{array}{c}\text { Very } \\
\text { Positive }\end{array}$ \\
\hline 4 & $\begin{array}{l}\text { The media helps students to } \\
\text { understand the material }\end{array}$ & $98 \%$ & $100 \%$ & $99 \%$ & $100 \%$ & $\begin{array}{c}\text { Very } \\
\text { Positive }\end{array}$ \\
\hline 5 & The media adds knowledge & $98 \%$ & $100 \%$ & $97 \%$ & $100 \%$ & $\begin{array}{c}\text { Very } \\
\text { Positive }\end{array}$ \\
\hline 6 & $\begin{array}{l}\text { The language is easy to } \\
\text { understand }\end{array}$ & $98 \%$ & $100 \%$ & $97 \%$ & $100 \%$ & $\begin{array}{c}\text { Very } \\
\text { Positive }\end{array}$ \\
\hline 7 & $\begin{array}{l}\text { The questions on the media is } \\
\text { suitable }\end{array}$ & $99 \%$ & $100 \%$ & $97 \%$ & $80 \%$ & $\begin{array}{c}\text { Very } \\
\text { Positive }\end{array}$ \\
\hline 8 & $\begin{array}{l}\text { The media increases the spirit } \\
\text { of learning }\end{array}$ & $98 \%$ & $100 \%$ & $98 \%$ & $100 \%$ & $\begin{array}{c}\text { Very } \\
\text { Positive }\end{array}$ \\
\hline 9 & $\begin{array}{l}\text { The material is easy to } \\
\text { understand }\end{array}$ & $98 \%$ & $100 \%$ & $97 \%$ & $100 \%$ & $\begin{array}{c}\text { Very } \\
\text { Positive }\end{array}$ \\
\hline 10 & Images in comics is attractive & $97 \%$ & $100 \%$ & $98 \%$ & $100 \%$ & $\begin{array}{c}\text { Very } \\
\text { Positive }\end{array}$ \\
\hline Perc & ntage Of Responses (Average) & $98 \%$ & $98 \%$ & $98 \%$ & $98 \%$ & $\begin{array}{c}\text { Very } \\
\text { Positive }\end{array}$ \\
\hline
\end{tabular}


From the processing of statistics data Table 1, comic media can be concluded based on mind mapping valid and feasible to use. Based on Table 2 until Table 12, it can be concluded that mind mapping-based comic media is effectively used in mathematics learning class V SDN Gugus Sultan Agung Demak Regency. This aspect of media practicality is measured by a response questionnaire about mind mapping-based comic media in learning. Recapitulation of student and teacher response questionnaires is in table 13. In general, practical media is used in learning seen from several aspects, including attracting and motivating studennts' learning, language and materials are easy to understand, images in comics and problem forms in comics get positive responses from students and teachers.

\section{DISCUSSION}

\section{Validity of Mind Mapping Based Mathematics Comic Media}

There are three aspects of assessing mathematical comic media's appearance based on mind mapping, namely about the presentation, simplicity, and suitability of images in learning media. This comic's advantage is presenting images in comics according to illustrations and can clarify the storyline. This statement follows the results of other studies that state the comic's image can bring to life the accompanying series of the written text to clarify the information (Indaryati \& Jailani, 2015). Also, the colourfully printed mathematical comic media can develop learning activities through learning experiences. This statement is supported by other research results showing that colouring and emphasis on learning activities based on learning experience are essential for comic media making (Putra \& Iqbal, 2004).

There are three assessment indicators from the material aspect, namely suitability, completeness, and feasibility. The speed and discharge material in mind mapping-based mathematics comics are suitable for learning objectives to be achieved. Then, according to the complexity of the learning material, it is easy to understand and can improve students' understanding. This statement is under Arsyad's opinion (2016), which states that learning media should support the content of lessons that are fact, concept, and generalization to improve students' understanding. The high validation results are in line with the results of material validation from the research of Widyastuti, Mardiyana, and Saputro (2017). The mathematical material presentation must be convinced about the truth of mathematical concepts and no mistakes in writing symbols (Widyastuti, Mardiyana, \& Saputro, 2017).

The speed and discharge material presented in this mathematical comic medium can be found in the conversation section and the mind map section. The conversation section is presented contextual examples of material in everyday life, especially with the cultural background of Demak city, including understanding and examples of material-related problems. Through contextual problems in comics, making mathematics learning more meaningful (Syutaridho, 2019).

The language used in this mathematics comic has used good and Indonesian's standard. Also, the language used related to the word and dialogue in the story suit to the fifth-grade of elementary students' level of thinking. Language, word structure, and message are easy for students to understand and in accordance with the development of the student's language which can lead understanding (Usman in Syria, 2018) which states that the selection of words in the learning media should not be too difficult for students because it can cause chaos of interpretation.

Based on the validation results of media experts, materials, and language of mathematics, comic media based on mind mapping meets the criteria, and it is valid and worth to be used as a learning media. Mind mapping-based mathematics comic media can be used for trials and trials in elementary school grade V students. 
Furthermore, an assessment of students' problem-solving skills. Here is an example of a Student Worksheet (LKS) on speed and discharge skills. Assessment of problemsolving skills of speed and discharge material is measured from the worksheet, using rubrics, with a maximum score of 4 in each aspect assessed. Some of the diagnostic test questions contain stories about speed and discharge, as in Table 14.

TABLE 14. Problem Stories In Diagnostic Tests

\begin{tabular}{ccl}
\hline Number & Material & \multicolumn{1}{c}{ About the story } \\
\hline 1 & Speed & $\begin{array}{l}\text { The distance of Demak City - Kebumen is 190 km. Pak Bambang } \\
\text { departed from Demak at 09.00 and arrived in Kebumen at 11:45. If } \\
\text { Pak Bambang rests once for 15 minutes, then the average speed of } \\
\text { the vehicle driven by Pak Bambang is..... } \\
\text { The volume of water in the pool was initially 16.8 m3. After watering } \\
\text { for 80 minutes using a water pump, the volume becomes 60m3. The } \\
\text { discharge of water flow through the pump is.... }\end{array}$ \\
\hline
\end{tabular}

If the problem in the diagnostic test for speed and discharge material compared to the problems in worksheet (Figure 5 and Figure 6), there are some similarities and differences. The similarity is in the indicator measured related to solving even though in worksheet focuses on problem-solving. The difference is that diagnostic tests are presented in multiple-choice form, while in the worksheet, they are presented in a gradual description. It is expected that through this worksheet, students can organize reason starting from knowing the information in the story and understanding the question, then rare-step completion is given a gradual reference.

The worksheet is considered using rubrics to look at aspects of understanding the problem and solve the problem. The rubric results showed $100 \%$ grades, which meant that students could understand, plan, and solve speed material problems through concrete steps. However, on the discharge material on understanding the problem, planning the problem's solution, and implementing the problem solving, the percentage is $83 \%$. The high percentage gain is due to the presentation of material submitted through images, and verbal emblems in comics can provide clear information, thereby increasing students' understanding of the material.

\section{Effectiveness and Practicality of Mind Mapping Based Mathematics Comic Media}

Based on the results of product trials and usage tests, mind mapping-based mathematical comic media influences students' cognitive learning outcomes of speed and discharge materials. The data analysis results showed that there were differences in students' cognitive learning outcomes before and after using mind mapping-based mathematical comic media.

Furthermore, $\mathrm{n}$ gain test results, there was an average increase before and after using mind mapping-based mathematical comic media in learning activities of 0.57 on a small scale and 0.54 on a large scale, both included in the moderate criteria. The effectiveness of using mathematics comic media based on mind mapping is shown by achieving the completeness of students' learning individually 70 and classical completeness of $75 \%$.

Qualitatively, students and teachers' responses about mathematics comic media based on mind mapping through questionnaires of responses filled by students and teachers. The product trial activities received very positive responses from students and teachers of SD N Sari 1, 98\% each, meaning that students and teachers rated this media very well.

In the test, mind mapping-based mathematics comic media also received very positive responses from students and teachers of SD N Banjarsari 1,98\% each. Teachers consider learning media to be very practical and very helpful in learning mathematics, 
especially speed and discharge materials. Students who use mathematics learning media in comics make them eager to learn and easy to understand learning. Students are also enthusiastic about the comic background that raises the topic of demak culture where they live.

Based on the above research results, mind mapping-based comic media effectively improves students' learning outcomes of speed and discharge material. Mind mapping in the comic shows an overview of the relation of speed material with the material about the measurement of distance and time and various standard units that are often used. The presentation of material delivered through images and verbal emblems in comics can provide clear information and make it easier for students to understand the material. It is in accordance with the results of Yulian's research (2018). The results showed that $86 \%$ of students stated that it is easier to use comic media because it is accompanied by words and images that support each other (Yulian, 2018). Mind mapping in comics also helps students remember and develop mathematical concepts. It is in accordance with the research of Purwanti and Ahmad (2016), which stated that the mind map could help develop an idea or idea.

Based on the final study results above, it was concluded that the comic media developed has been feasible to be used in learning mathematics materials speed and discharge grade $\mathrm{V}$ elementary school. Thus, mind mapping-based mathematics comic media can be implemented according to the objectives, namely improving students' learning outcomes in learning math speed and discharge materials.

\section{CONCLUSION}

Based on the results of research and discussion, it was concluded that the mathematics comic media based on mind mapping was successfully developed by adapting the seven steps of sugiyono model development stage, includes: 1) potential and problems, 2) data collection, 3) product design, 4) design validation, 5) design revision, 6) product trial, 7) usage test. Characteristics of mathematics comic media based on mind mapping is mind map as the basis that shows the interconnectedness of materials ranging from understanding, formulas, examples of problems in daily life and the steps of completion, equipped with the cultural background of demak city as an effort to introduce and preserve regional culture. Mind mapping-based mathematical comic media is declared valid and feasible after being rated highly feasible by media experts, material experts and linguists. This media's effectiveness on speed and discharge material is successfully proven by the improvement of learning outcomes, the achievement of individual and classical learning completeness. Furthermore, aspects of media practicality are responded positively by teachers and students in terms of content and appearance of mathematics comic media based on mind mapping. So the media of mathematics comics based on mind mapping that is equipped with daily problems and cultural context has qualified valid, effective and practical.

This research's advice is that after studying the material and reading the mind map in the mathematics comics, students need to be assigned to create their mind map as an act of reflection at the end of the learning.

\section{REFERENCES}

1. Arsana, I. K., Suarjana, M., \& Arini, N. W. (2019). Pengaruh Penggunaan Mind Mapping berbantuan Alat Peraga Tangga Garis Bilangan terhadap Hasil Belajar Matematika. International Journl of Elementary Education, 3(2), 99-107.

2. Arsyad, A. (2013). Media Pembelajaran. Jakarta: Pt Rajagrafindo Persada

3. Buchori, A., \& Setyawati, R. D. (2015). Development learning model of character education through e-comic in elementary school. International Journal of Education and Research, 3(9), 369-386. 
4. Buzan, T. (2012). The Ultimate Book of Mind Maps. United Kingdom: HarperCollins Publishers.

5. Dewi, N. P. Y., Ganing, N. N., \& Wayan, S. I. (2020). Comic Media Assisted SQ3R Method Influence Students Comprehensive Reading Skills. Journal of Education Technology, 4(3), 331-339.

6. Gumilang, M. R., \& Indarini, E. (2019). Pengembangan Media Komik dengan Model Problem Posing untuk Meningkatkan Kemampuan Pemecahan Masalah Matematika. Journal of Medives, 3(2), 185-196.

7. Hardman, J. (2019). Towards a pedagogical model of teaching with ICTs for mathematics attainment in primary school: A review of studies 2008-2018. Heliyon, 5(5), e01726. https://doi.org/10.1016/j.heliyon.2019.e01726

8. Indaryati, \& Jailani. (2015). Pengembangan Media Komik Pembelajaran Matematika Meningkatkan Motivasi Dan Prestasi Belajar Siswa Kelas V. Jurnal Prima Edukasia, 3(1), 84-96.

9. Kementerian Pendidikan dan Kebudayaan. (2020). Pusat Penilaian Pendidikan. In Kementerian Pendidikan dan Kebudayaan. Indonesia.

10. Kementerian Pendidikan dan Kebudayaan. (2016). Permendikbud No 21 Tahun 2016 Tentang Standar Isi Pendidikan Dasar dan Menengah. Jakarta: Kemendikbud

11. Kurniati, D., Rahimah, D., \& Rusdi. (2017). Efektivitas Komik pada Materi Sifat-Sifat Bangun Ruang Untuk Siswa kelas V SD Negeri 61 Kota Bengkulu. Jurnal Penelitian Pembelajaran Matematika Sekolah (JP2MS), 1(1).

12. Mullis, ina V., Martin, M. O., Foy, P., \& Hooper, M. (2015). TIMMS 2015 International Result in Mathematics. In The SAGE Encyclopedia of Educational Research, Measurement, and Evaluation. https://doi.org/10.4135/9781506326139.n704

13. Nasarudin. (2013). Karakteristik dan Ruang Lingkup Pembelajaran Matematika di Sekolah. Al-Khwarizmi, 2, 63-76.

14. Nendasariruna, T., Masjudin, \& Abidin, Z. (2018). Pengembangan komik matematika berbasis kontekstual pada materi persegi panjang bagi siswa kelas vii. Jurnal Media Pendidikan Matematika, 4(2), 76-79.

15. Nova, T., \& Yunianta, H. (2018). Pengembangan Media Komik Matematikapada Materi Pecahan Untuk Siswa Kelas V Sekolah Dasar. MAJU, 5(1), 79-90.

16. Nugraheni, N. (2017). Penerapan Media Komik Pada Pembelajaran Matematika. Jurnal Refleksi Edukatika, 7(2), 111-117.

17. Pajarini, P., Putra, S., \& Manuaba, S. (2014). Pengaruh Penerapan Pembelajaran Kontekstual Berbasis Mind Mapping Terhadap Hasil Belajar Matematika Siswa Kelas V SD. E-Journal Mimbar PGSD Universitas Pendidikan Ganesha, 2(1), 1-10.

18. Purwanti, \& Ahmad, A. (2016). Peningkatan Komunikasi Matematis dan Kemandirian Belajar Siswa melalui Pendekatan Problem Posing berbantuan Mind Map. Jurnal Didaktik Matematika, 3(2), 19-34.

19. Putra, P. D. A., \& Iqbal, M. (2004). Implementation of Digital Comic to Improve Creative Thinking Ability in Integrated Science Study. International Conference on Mathematics, Sciences, and Education, 1-4.

20. Siregar, P. A., \& Rosaliana, S. (2017). Pengaruh Penggunaan Media Komik Matematika Dengan Bantuan Powerpoint Terhadap Motivasi dan Hasil Belajar Matematika Siswa Di SMK Istiqlal Delitua. MES (Journal of Mathematics Education and Science), 3(1), 91100.

21. Sugiyono. (2015). Metode Penelitian Pendidikan (Pendekatan Kuantitatif, Kualitatif, Dan R\&D). Bandung: Alfabeta

22. Sumartini, T. S. (2016). Peningkatan Kemampuan Pemecahan Masalah Matematis Siswa melalui Pembelajaran Berbasis Masalah. Jurnal Mosharafa, 5(2), 148-158.

23. Suryani, N., Setiawan, A, \& Putria, . (2018). Media Pembelajaran Inovatif dan Pengembangannya. Bandung: PT Remaja Rosdakarya

24. Suryatin, S., \& Sugiman, S. (2019). Comic book for improving the elementary school students ' mathematical problem solving skills and self-confidence. Jurnla Prima 
Edukasia, 7(1), 58-72.

25. Syutaridho. (2019). Pengembangan Bahan Ajar Bangun Datar dengan Pendekatan Contextual Teaching and Learning. Jurnal Pendidikan Matematika RAFA, 5(1), 41-56.

26. Widyastuti1, P. D., Mardiyana, M., \& Saputro, D. R. S. (2017). An Instructional Media using Comics on the Systems of Linear Equation. Journal of Physics: Conference Series PAPER.

27. Yulian. (2018). Developing Teaching Materials Using Comic Media to Enhance Students' Mathematical Communication. IOP Conference Series: Materials Science and Engineering PAPER. https://doi.org/10.1088/1757-899X/335/1/012110

28. Zahro, F., Degeng, I. N. S., \& Mudiono, A. (2018). Pengaruh model pembelajaran student team achievement devision (STAD) dan mind mapping terhadap hasil belajar siswa kelas IV sekolah dasar. Premiere Educandum: Jurnal Pendidikan Dasar Dan Pembelajaran, 8(2), 196-205. https://doi.org/10.25273/pe.v8i2.3021

29. Zubaidah, S., Fuad, N. M., Mahanal, S., \& Suarsini, E. (2017). Improving Creative Thinking Skills of Students through Differentiated Science Inquiry Integrated with Mind Map. Journal of Turkish Science Education, 14(4), 77-91. https://doi.org/10.12973/tused.10214a

\section{PROFILE}

Trimurtini is a lecturer in elementary school teacher education program (PGSD), Faculty of Education, Universitas Negeri Semarang. She is active in research and education to the community in the field of mathematics learning. In addition, she is a national reviewer of the Student Creativity Program (PKM) Dikti.

Mira Amalia Setyani is an alumnus of the Elementary School Teacher Education program, Faculty of Education, Universitas Negeri Semarang. She has great motivation in mathematics learning research in elementary school.

Elok Fariha Sari is a lecturer in the study program of Elementary School Teacher Education, Faculty of Education, Universitas Negeri Semarang. In addition, she is active in research in the field of Elementary Mathematics Learning.

Nursiwi Nugraheni is a lecturer in the study program of Elementary School Teacher Education, Faculty of Education, Universitas Negeri Semarang. She also reviewed several articles in the Journal of Medives: Journal of Mathematics Education IKIP Veteran Semarang. In addition, she is active in research projects in the field of mathematics learning. 